\title{
Update on the therapeutic significance of estrogen receptor beta in malignant gliomas
}

\author{
Yu-Long Lan ${ }^{1,2,3, *}$, Shuang Zou ${ }^{3,4, *}$, Xun Wang ${ }^{1}$, Jia-Cheng Lou ${ }^{1}$, Jin-Shan Xing ${ }^{1}$, Min \\ Yú ${ }^{5}$ and Bo Zhang ${ }^{1}$ \\ ${ }^{1}$ Department of Neurosurgery, The Second Affiliated Hospital of Dalian Medical University, Dalian, 116023, China \\ ${ }^{2}$ Department of Pharmacy, Dalian Medical University, Dalian, 116044, China \\ ${ }^{3}$ Department of Physiology, Dalian Medical University, Dalian, 116044, China \\ ${ }^{4}$ Department of Neurology, The First Affiliated Hospital of Dalian Medical University, Dalian, 116011, China \\ ${ }^{5}$ Department of Neurology, The Third People's Hospital of Dalian, Non-Directly Affiliated Hospital of Dalian Medical University, \\ Dalian, 116033, China \\ *These authors contributed equally to this work
}

Correspondence to: Bo Zhang, email: zhangbodl@126.com Min Yu, email: yumin1997@sina.com

Keywords: estrogen receptor $\beta$, glioma, expression, therapy

Received: June 22, $2017 \quad$ Accepted: August 29, $2017 \quad$ Published: September 18, 2017

Copyright: Lan et al. This is an open-access article distributed under the terms of the Creative Commons Attribution License 3.0 (CC BY 3.0), which permits unrestricted use, distribution, and reproduction in any medium, provided the original author and source are credited.

\section{ABSTRACT}

Malignant glioma is the most fatal of the astrocytic lineage tumors despite therapeutic advances. Men have a higher glioma incidence than women, indicating that estrogen level differences between men and women may influence glioma pathogenesis. However, the mechanism underlying the anticancer effects of estrogen has not been fully clarified and is complicated by the presence of several distinct estrogen receptor types and the identification of a growing number of estrogen receptor splice variants. Specifically, it is generally accepted that estrogen receptor alpha (ERa) functions as a tumor promoter, while estrogen receptor beta (ER $\beta$ ) functions as a tumor suppressor, and the role and therapeutic significance of ER $\beta$ signaling in gliomas remains elusive. Thus, a deeper analysis of ER $\beta$ could elucidate the role of estrogens in gender-related cancer incidence. ER $\beta$ has been found to be involved in complex interactions with malignant gliomas. In addition, the prognostic value of ER $\beta$ expression in glioma patients should not be ignored when considering translating experimental findings to clinical practice. More importantly, several potential drugs consisting of selective ER $\beta$ agonists have exhibited anti-glioma activities and could further extend the therapeutic potential of ER $\beta$-selective agonists. Here, we review the literature to clarify the anti-glioma effect of ERB. To clarify ER $\beta-$ mediated treatment effects in malignant gliomas, this review focuses on the potential mechanisms mediated by ER $\beta$ in the intracellular signaling events in glioma cells, the prognostic value of ER $\beta$ expression in glioma patients, and various ER $\beta$ agonists that could be potential drugs with anti-glioma activities.

\section{INTRODUCTION}

Glioma is the most common primary malignant brain tumor and has a poor prognosis. Currently more efforts should be directed toward developing more efficacious and targeted therapeutic paradigms. A known gender bias exists in tumor development: women have a lower incidence than men, indicating protective effects of estrogen. Evidence from various sources indicates that endogenous estrogens could have beneficial effects against glioma development [1]. First, the descriptive epidemiology of brain gliomas suggests a higher incidence in males than in females, particularly during premenopausal years [2]. Using New York State 
tumor registry data, McKinley et al. [2] calculated the incidence rates of age- and sex-specific for three types of glial tumors: anaplastic astrocytoma, glioblastoma multiforme (GBM), and astrocytoma not otherwise specified. The authors calculated the rate ratio for GBM in women relative to men based on 5-year age intervals and demonstrated that men are approximately 1.5-2 times more likely to develop proportional GBM. Besides, the rate ratio for GBM in women compared with men continued to decrease throughout the premenopausal years. These findings could suggest a protective effect of estrogens against glioma, especially during the premenopausal years. Second, some gliomas express various estrogen receptors (ERs) as well as aromatase (an important enzyme for the conversion of testosterone to estradiol) [1]. Third, experimental studies have revealed that glioblastomas transplanted into animals showed a slower growth rate in females than in males [1]. Furthermore, estrogen increased survival in an orthotopic model of glioblastoma [3]. Elucidating hormonal pathways that are found to be potentially involved in gliomagenesis could help design tumor-preventive strategies. In addition, since steroid hormones could penetrate the blood-brain barrier (BBB), it may be necessary to examine the relationship between circulating steroid levels and the subsequent risk of glioma [4]. Further epidemiological, experimental, and clinical studies are necessary to elucidate the effects of estrogen and estrogen compounds on the growth and proliferation of malignant gliomas.

As a steroid hormone in humans, the biological function of estrogen is primarily mediated by binding to two classical receptors: estrogen receptor alpha $(\mathrm{ER} \alpha)$ and estrogen receptor beta $(\mathrm{ER} \beta)$, which were identified and cloned in 1986 and 1996, respectively [5]. Our understanding of the role of estrogen in various tissues and the role of these two estrogen receptor subtypes has greatly improved over the past twenty years [6]. Because the expression of putative $G$ protein coupled receptors (GPR30) has not been studied in gliomas, it is not discussed in this article. ERs can combine estradiol and other estrogen compounds to form homodimers and/ or heterodimers. These dimers can also bind to a specific DNA sequence found in the regulatory regions of estrogenresponsive genes, called the estrogen response element (ERE), and recruit other components of the transcriptional machinery, thereby affecting gene expression [6, 7]. A number of coactivators and corepressors can modulate receptor function [7]. Furthermore, estradiol and other steroid hormones as well as selective estrogen receptor modulators (SERMs) can act through non-classical pathways (i.e., not directly involving ERs binding to EREs) $[6,7]$.

Although $\mathrm{ER} \alpha$ and $\mathrm{ER} \beta$ are structurally similar, their ligand binding domains actually exist sufficient differences to allow them to be selective for different ligands [8]. Recent studies have indicated that ER $\beta$ has a markedly different function than ER $\alpha$ [9] and is generally considered to be a tumor suppressor. Although $\mathrm{ER} \alpha$ is detected in approximately $1 / 3$ of all low-grade tumors [10], it has been reported that most gliomas are $\mathrm{ER} \alpha$ negative [5]. ER $\alpha$ plays more prominent roles in the uterus and mammary gland, regulating metabolism, and preserving bone homeostasis, while ER $\beta$ could be of more pronounced effects on the central nervous system (CNS) [11]. Currently, the precise function, regulation, and mechanisms of action of $\mathrm{ER} \alpha$ in human glioma are unknown. However, it is possible that $\mathrm{ER} \alpha$ is reduced or absent during tumor development. Different from $\mathrm{ER} \alpha$, $\mathrm{ER} \beta$ is expressed in glial neoplasms [12] and in nonneoplastic astrocytes [5]. Batistatou et al. [5] reported that the expression of ER $\beta$ was decreased in high-grade tumor tissues in parallel with their loss of differentiation. In other cancers, including prostate, breast, and ovarian cancers, the decrease or absence of ER $\beta$ is associated with a malignant phenotype, indicating that $\operatorname{ER} \beta$ has a potential inhibitory effect on cancer [13-16]. In addition, it has been demonstrated that ER $\beta$ overexpression reduces cell proliferation whereas $\operatorname{ER} \beta$ knockdown enhances cell proliferation in breast and colon cancer cells [17-19]. Although these studies suggest that ER $\beta$ has tumor-suppressive potential in some tumors, the role and therapeutic significance of ER $\beta$ signaling in gliomas remains elusive.

Given these research findings regarding the role of ER $\beta$ in preventing glioma, the protective effects of estrogen signaling cannot be ignored. The status and exact role of estrogen and ERs in glioma requires further research, and here, we review the literature regarding the roles of ER $\beta$ in malignant gliomas (Table 1). A thorough study of the role of ER $\beta$ in the genesis and development of diseases of the central nervous system (CNS) holds important clinical significance and could serve as a guide for the treatment of malignant glioma. Therefore, it is critically important to investigate ER $\beta$ with respect to the mechanism of its signal transduction pathway and, particularly, its correlation with glioma incidence.

\section{ERß HAS COMPLEX INTERACTIONS WITH MALIGNANT GLIOMAS}

Significant research efforts have been directed toward clarifying the relationship between malignant glioma and ER $\beta$ and investigating nuclear ER $\beta$ and the cytoplasmic part of ER $\beta$, which have been shown to significantly influence glioma. Dominguez et al. [20] showed that estradiol rapidly regulates membrane ERs levels in hypothalamic neurons, which suggests that estrogen can regulate its own membrane signaling. Because the effects of estrogens are mediated largely through canonical ERs, primarily $\mathrm{ER} \alpha$ and $\mathrm{ER} \beta$, the alterations in ERs levels that are observed in various regions of the brain in patients with glioma may be relevant to cancer 
Table 1: Published studies investigating the roles of ER $\beta$ in malignant gliomas

\begin{tabular}{|c|c|c|c|c|}
\hline Series & Year & Journal & Country & Results \\
\hline Batistatou A, et al. & 2004 & $\begin{array}{l}\text { Journal of Cancer Research and } \\
\text { Clinical Oncology }\end{array}$ & Greece & $\begin{array}{l}\text { ER } \beta \text { is mainly expressed in astrocytes } \\
\text { of low-grade gliomas and in normal } \\
\text { astrocytes. Its presence decreases with } \\
\text { increased malignancy of these tumors. }\end{array}$ \\
\hline Batistatou A, et al. & 2006 & Journal of Neuro-Oncology & Greece & $\begin{array}{l}\text { ER } \beta \text { is found to be expressed in gliomas } \\
\text { and oligodendrogliomas. ER } \beta \text { expression } \\
\text { tends to decrease with increased } \\
\text { histological malignancy of the tumor. } \\
\text { Patients with ER } \beta \text {-positive tumors could } \\
\text { be of better prognosis and longer survival } \\
\text { times. }\end{array}$ \\
\hline Kim J,H et al. & 2011 & BMB Reports & Korea & $\begin{array}{l}\text { ER } \beta \text { promoted up-regulation of Egr- } 1 \\
\text { expression via a non-genomic mechanism } \\
\text { involving the Raf/MEK1/Erk/Elk-1 } \\
\text { signaling cascade. }\end{array}$ \\
\hline Kefalopoulou Z, et al. & 2012 & Journal of Neuro-Oncology & Greece & $\begin{array}{l}\text { ER } \beta \text { and ER co-activators AIB1, TIF2, } \\
\text { and PELP1 appear to play an important } \\
\text { role in the pathogenesis and progression } \\
\text { of astrocytic tumors and might have } \\
\text { prognostic significance. The mechanisms } \\
\text { underlying their involvement in astrocytic } \\
\text { tumorigenesis, as well as their utility for } \\
\text { prognostic and therapeutic purposes merit } \\
\text { further investigation. }\end{array}$ \\
\hline Sareddy G,R et al. & 2012 & Molecular Cancer Therapeutics & USA & $\begin{array}{l}\text { ER } \beta \text { signaling has a tumor-suppressive } \\
\text { function in gliomas. Because ER } \beta \\
\text { agonists are currently in clinical trials } \\
\text { and are well tolerated with fewer side } \\
\text { effects, identification of an ER } \beta \text { agonist } \\
\text { as a therapeutic agent can be readily } \\
\text { extended to clinical use with current } \\
\text { chemotherapies. }\end{array}$ \\
\hline Li W, et al. & 2013 & Brain Research & USA & $\begin{array}{l}\mathrm{ER} \beta 5 \text { is the main ER } \beta \text { isoform found } \\
\text { in gliomas. Hypoxia induced ER } \beta 5 \\
\text { expression in glioma as a self-protective } \\
\text { mechanism against tumor proliferation } \\
\text { and that ER } \beta 5 \text { might serve as a therapeutic } \\
\text { target for the treatment of glioma. }\end{array}$ \\
\hline Liu C, et al. & 2014 & Cancer Epidemiology & China & $\begin{array}{l}\text { This study indicated a combination } \\
\text { of decreased expression of ERs, } \\
\text { including ER } \beta \text {, may be involved in the } \\
\text { tumorigenesis of gliomas. }\end{array}$ \\
\hline Liu X, et al. & 2015 & Molecular Medicine Reports & China & $\begin{array}{l}\text { enhanced ER } \beta \text { expression and sensitized } \\
\text { glioma cells to TMZ-induced proliferation } \\
\text { inhibition via the PI3K/AKT/mTOR } \\
\text { pathway. }\end{array}$ \\
\hline
\end{tabular}

Abbreviations: TMZ: temozolomide.

malignancy. Further research has indicated that changes in cellular ER $\beta$-mediated signaling could compromise the neuroprotective effects of estrogen and thereby contribute to the clinical progression of malignant glioma.
The action of ER $\beta$ is necessary for estrogen to exert its neuroprotective effect; therefore, it is critically important to clarify the signaling responses triggered by ER $\beta$ that are relevant for anti-glioma effects (Figure 1). 


\section{INCREASING ERß PROTEIN EXPRESSION AND NUCLEAR TRANSLOCATION MAY BE IMPORTANT FOR ACTIVATION OF THE ERB PATHWAY}

Sareddy et al. [21] have explored the use of beta agonists as a potential novel therapeutic option to inhibit glioma growth. First, they detected ER $\beta$ expression in six glioma model cell lines, whereas little or no ER $\alpha$ expression was detected. Immunohistochemical analysis of tumor tissues indicated the downregulation of ER $\beta$ expression in high-grade gliomas. Importantly, they found that the expression of $E R \beta$ was significantly higher in normal brain tissues and low-grade tumors than in high-grade tumors. ER $\beta$ expression was decreased during the progression of gliomas and high-grade gliomas expressed ER $\beta$ predominantly in the cytoplasm. In addition, ER $\beta$ agonist treatment can lead to a marked decrease in the proliferation of glioma cells. Furthermore, activation of the ER $\beta$ pathway via agonists has the potential to increase ER $\beta$ protein expression and nuclear translocation. These findings indicated that ER $\beta$ agonists can promote the expression of ER $\beta$ and promote the tumor suppressive function of ER $\beta$ in glioma cells by increasing ER $\beta$ expression and nuclear translocation.

The findings of Sareddy et al. [21] suggested that ER $\beta$-selective agonists such as DPN, MF101, and liquiritigenin have the potential to inhibit glioma cell proliferation and tumor growth. Thus, increased ER $\beta$ expression could be important for the effect of its agonists. Various ER $\beta$-selective drugs including DPN, ERB-041, MF101, and liquiritigenin are currently being investigated as a replacement for estrogens to treat menopausal symptoms [8, 9]. Furthermore, these ER $\beta$ agonists (DPN and liquiritigenin) have good BBB permeability and exert less neuronal toxicity $[22,23]$; hence, they are very suitable for the therapeutic treatment of gliomas.

\section{ER $\beta$ STIMULATES EGR-1 TRANSCRIPTION THROUGH THE MEK1/ERK/ELK-1 CASCADE IN GLIOMA CELLS}

The Egr-1 gene is an immediate early response gene that encodes a transcription factor that plays a regulatory

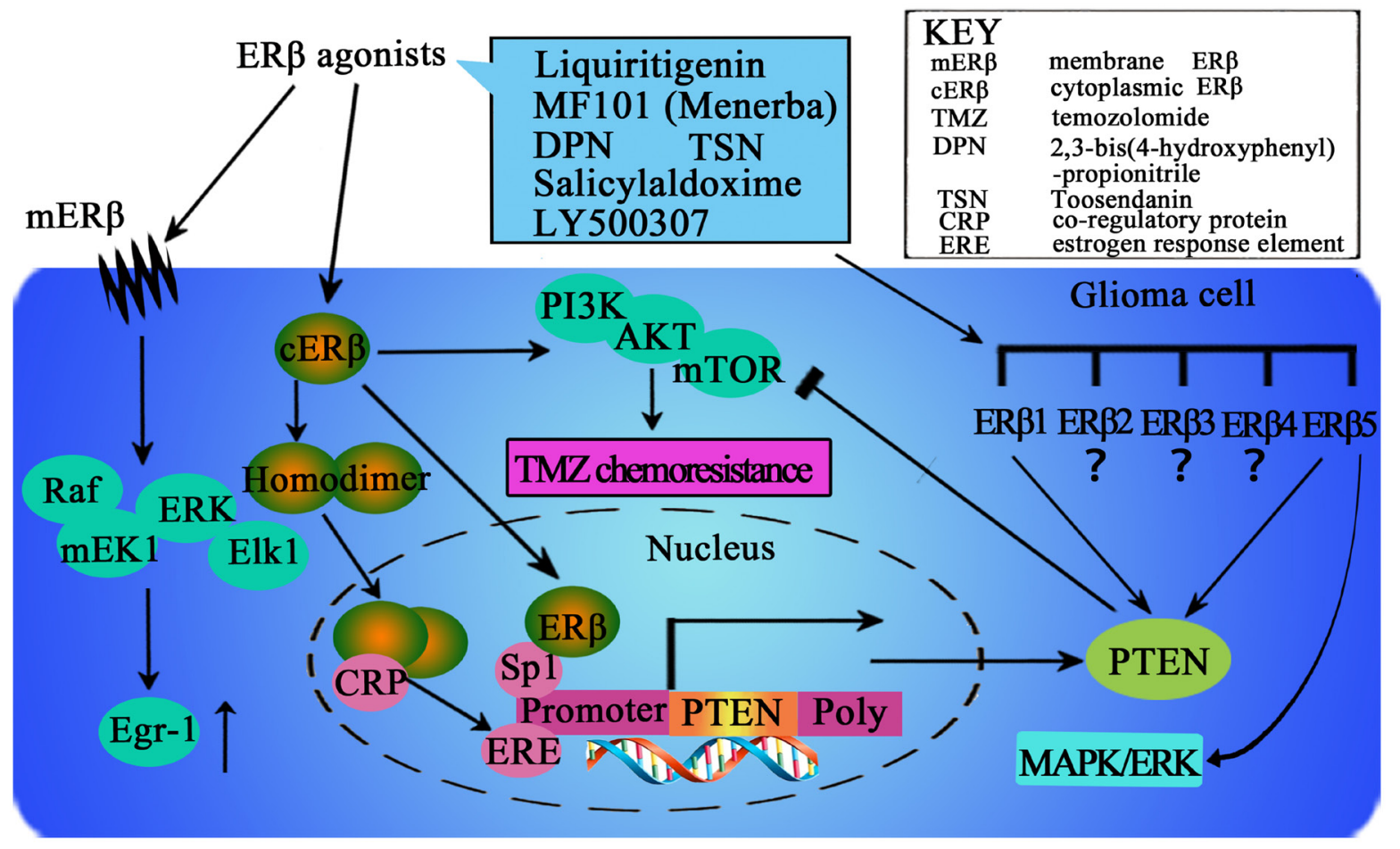

Figure 1: The potential mechanisms mediated by ERß in the intracellular signaling events in glioma cells. Increasing ER $\beta$ protein expression and nuclear translocation could be important for activation of the ER $\beta$ pathway. In addition, ER $\beta$ could stimulate Egr-1 transcription via the MEK1/Erk/Elk-1 cascade in glioma cells. Furthermore, ER $\beta$ agonist could enhance temozolomide sensitivity of glioma cells by inhibiting the PI3K/AKT/mTOR pathway. Ligand binding with ER $\beta$ could induce conformational changes that facilitate receptor dimerization to homodimers $(\mathrm{ER} \beta / \mathrm{ER} \beta)$, translocation of dimers to the nucleus, and binding with co-regulatory proteins $(\mathrm{CRP})$. This supra-molecular assembly thus may interact with the estrogen response element (ERE) in the promoter region of target genes. Furthermore, ER $\beta$ could also bind to the promoter region of PTEN through Sp1 and increase PTEN transcription. The presence of various ER $\beta$ isoforms could add further complexity to the action of ER $\beta$, which should be considered in clarifying the effects of ER $\beta$ in human glioma. However, it remains unclear which isoforms primarily exert anticancer effects in human glioma, and the distinct function of each ER $\beta$ isoform is unknown. More efforts should be directed toward clarifying the activation and agonist-induced dynamics of ER $\beta / E R \beta$ homodimers and the distinct function of each ER $\beta$ isoform to design more potent ligands that selectively activate ER $\beta$. 
role in cell growth, differentiation, and apoptosis. Kim et al. [24] investigated whether ER $\beta$ could induce Egr-1 expression in glioma cells that express ER $\beta$ but not ER $\alpha$. Their results showed that ER $\beta$ increased the expression of Egr-1 through a non-genomic mechanism involving the Raf/MEK1/Erk/Elk-1 signaling pathway.

ERs, including $\mathrm{ER} \alpha$ and $\mathrm{ER} \beta$, are traditionally considered transcription factors that bind to EREs in the promoter region, resulting in the regulation of gene expression [24]. However, a non-transcriptional mechanism of signal transduction via ER $\alpha$, the so-called non-genomic pathway, has been identified. Like ER $\alpha$, $\mathrm{ER} \beta$ at the cell membrane could also activate the nongenomic signaling pathway. In this investigation, the authors demonstrated that Erk1/2, rather than JNK1/2 or p38 MAPK, was promptly activated following $17 \beta-E 2$ treatment in C6 glioma cells, which only express ER $\beta$. Furthermore, pretreatment with the MEK1 inhibitor U0126 and the expression of dn mutants of MEK1, Erk2, or Raf1, blocked Egr-1 expression by ER $\beta$. Thus similar to $\mathrm{ER} \alpha, \mathrm{ER} \beta$ induces Egr-1 expressionvia activation of the Raf/MEK1/ERK/ELK-1 signaling pathway.

\section{ER $\beta$ AGONIST ENHANCES TEMOZOLOMIDE SENSITIVITY OF GLIOMA CELLS BY INHIBITING THE PI3K/AKT/MTOR PATHWAY}

Temozolomide (TMZ) is a common first-line postsurgical drug used for malignant gliomas. However, the efficacy of TMZ is still poor because genetic resistance could be often observed. As mentioned above, $\mathrm{ER} \beta$ has become an important tumor suppressor, as well as a key regulator of signal transduction in glioma cells; however, little is known regarding the role of $\mathrm{ER} \beta$ in the chemotherapeutic response to TMZ. It is well known that $\mathrm{PI} 3 \mathrm{~K} / \mathrm{AKT} / \mathrm{mTOR}$ signaling plays a critical role in regulating protein synthesis, proliferation and survival and has been implicated in multiple drug resistance (MDR) in a variety of cancer types. Sveral key components of this pathway, including PI3K, AKT, epidermal growth factor receptor (EGFR) and Ras, have been observed to be frequently mutated in most tumor cells and are significantly related to the hyperactivation of this pathway [25]. Independent of O-6-methylguanineDNA methyltransferase (MGMT, a DNA repair protein encoded by the MGMT gene that can remove cytotoxic and mutagenic adducts from the $\mathrm{O}^{6}$-guanine of DNA) function, the PI3K/AKT/mTOR signaling pathway may help to promote the expression of a series of anti-apoptotic factors and activate survival signals, which rid the cells of the cytotoxic effects caused by TMZ treatment $[25,26]$.

Using the novel highly selective ER $\beta$ agonist liquiritigenin and TMZ-resistant U138 glioma cells, Liu et al. [27] suggested that liquiritigenin treatment could enhance glioma cell susceptibility to TMZ through inhibiting the PI3K/AKT/mTOR pathway. They also suggested that function of liquiritigenin is dependent on ER $\beta$ and may be counterbalanced by IGF-1, which is a $\mathrm{PI} 3 \mathrm{~K} / \mathrm{AKT} / \mathrm{mTOR}$ activator. These results revealed a new MGMT-dependent mechanism of TMZ resistance, and emphasized the clinical use of liquiritigenin for improving the efficacy of TMZ. Because excessive activation of the $\mathrm{PI} 3 \mathrm{~K} / \mathrm{AKT} / \mathrm{mTOR}$ pathway is common in gliomas, the combined use of ER $\beta$ agonists may be a viable and effective treatment option to combat TMZ chemoresistance.

TMZ treatment in conjunction with liquiritigenin has been demonstrated to be a feasible therapeutic option with several benefits [27]. First, liquiritigenin was observed to be well tolerated, with almost no neuronal toxicity in phase II and III clinical trials [47, 48]. Second, liquiritigenin possesses strong BBB permeability capability and is able to reach the glioma cells $[22,23]$. Third, ER $\beta$ agonists can selectively target cells expressing ER $\beta$, making them more specific than other PI3K/mTOR inhibitors. Finally, the authors suggested that in addition to its role in decreasing TMZ resistance, liquiritigenin may also increase ER $\beta$ expression and inhibit tumor proliferation by activating the function of this well-known tumor suppressor [27]. These findings indicate that treatment with ER $\beta$ agonists may be a promising therapy for overcoming TMZ chemoresistance in human malignant glioma cells.

\section{THE PRESENCE OF VARIOUS ERß ISOFORMS ADDS FURTHER COMPLEXITY TO THE ACTION OF ERß THAT SHOULD BE CONSIDERED IN CLARIFYING THE EFFECTS OF ERß IN HUMAN GLIOMA}

$\mathrm{ER} \beta$ has been found to be a potential tumor suppressor as mentioned above. Further identification of various ER $\beta$ isoforms further increases the complexity regarding the biomedical role of $\operatorname{ER} \beta$ [28]. At present, at least 5 different ER $\beta$ isoforms have been identified, which have identical $\mathrm{N}$-terminal sequences but diverge from amino acid 469 to the C-terminus [28]. In vitro analyses have revealed that each ER $\beta$ isoform has distinct transcriptional activity $[28,29]$. The expression levels and functions of the different ER $\beta$ isoforms in breast cancer have also been studied and clarified [30, 31, 32]. Most studies on the expression of ER $\beta$ in cancer have used antibodies that do not distinguish between different ER $\beta$ isoforms, and much of the research on the function of ER $\beta$ in cancer has focused on the subtype of ER $\beta 1$. Various recent studies have indicated the great significance of aberrant ER $\beta$ expression in human glioma, its decreasing expression in high-grade tumors, and the inhibitory effect 
of ER $\beta$ agonist on the proliferation of glioblastoma cell lines $[12,21]$. However, only immunohistochemistry was used to evaluate ER $\beta$ expression in these studies. At present, the expression of these isoforms in human gliomas is unclear, and the specific function of each ER $\beta$ subtype is also unknown for the time being.

Li et al. [33] have evaluated the expression of ER $\beta$ isoforms in human glioma using immunohistochemistry, real-time PCR, and Western blotting. In their study, they identified that ER $\beta 5$ is the predominant isoform of ER $\beta$ in human glioma. They found that over-expression of either ER $\beta 1$ or ER $\beta 5$ increased PTEN expression and, thus, inhibited activation of the PI3K/AKT/mTOR pathway. As ER $\beta$ over-expression increases PTEN levels in a ligandindependent manner [34], it could be speculated that upregulation of PTEN protein expression is a common anti-tumor mechanism of ER $\beta$; however, this experiment was performed using $293 \mathrm{~T}$ cells rather than glioma cells. Nonetheless, an in-frame deletion causes U87 glioma cells to be devoid of functional PTEN [35]. Further studies using glioma cell lines without a PTEN mutation are necessary to further support this prediction. The C-terminal ligand-binding domain (LBD) is considered to be the key structural domain of $\operatorname{ER} \beta$, controlling ligand-dependent regulation of the ER signaling pathway. Ligand binding in the LBD could induce conformational changes that facilitate receptor dimerization to form homodimers $(E R \beta / E R \beta)$, translocation of dimers to the nucleus, and further binding with co-regulatory proteins [56]. This supra-molecular assembly finally interacts to the ERE in the promoter region of target genes [56]. In particular, the activation and agonist-induced dynamics of ER $\beta / E R \beta$ homodimer need to be explored to design more potent ligands that selectively activate the ER $\beta \beta$ homodimer. In addition, a recent study showed that ER $\beta$ can also increase transcription and expression of PTEN by binding the promoter region of PTEN via Sp1 [36]. The inhibitory effect of ER $\beta 1$ and ER $\beta 5$ on glioma cell proliferation identified currently also supports PTENindependent mechanisms. In addition, the authors found that ER $\beta 5$ could inhibit the MAPK/ERK pathway. Their findings indicated that hypoxia-induced ER $\beta 5$ expression in gliomas may be a self-protective mechanism against tumor proliferation, and ER $\beta 5$ could be the therapeutic target for glioma treatment.

\section{THE PROGNOSTIC VALUE OF ERß EXPRESSION IN GLIOMA PATIENTS COULD BE TRANSLATED INTO CLINICAL PRACTICE}

Batistatou et al. [5] for the first time monitored ER $\beta$ expression immunohistochemically in 56 cases of astrocytomas of all grades (grade I-IV) and in adjacent non-neoplastic brain tissue. The authors demonstrated that moderate or strong nuclear immunopositivity was obtained in non-neoplastic astrocytes and in lowgrade astrocytomas, whereas the majority of highgrade tumors were immunonegative or displayed weak immunoreactivity [5]. Intriguingly, there was a progressive decline in ER $\beta$ expression that paralleled the increase in tumor grade.

Interestingly, Batistatou et al. [12] further demonstrated that low ER $\beta$ expression was significantly correlated with high-grade tumors and worse survival in patients with astrocytic tumors. Multivariate analysis showed that ER $\beta$ expression had a prognostic value for overall survival in these patients [12]. Their results strengthen the hypothesis that ER $\beta$ could be of important role in the pathogenesis and progression of glial neoplasms [12]. In addition, ER $\beta$ protein expression could be a useful marker for identifying patients with better prognosis. The authors demonstrated that ER $\beta$ expression could be used as an independent prognostic marker for overall survival in patients with astrocytic tumors. To our knowledge, this is the first study to suggest that ER $\beta$ is important for prognostic evaluation in patients with astrocytic tumors. Although the sample size of this study was relatively small, the findings strongly favor a predictive effect of ER $\beta$ expression in the mortality of patients with astrocytic tumors. More research is needed to confirm these results, and further studies are needed to identify whether treatment strategies targeting ER $\beta$ are beneficial in gliomas.

Furthermore, Kefalopoulou et al. [37] for the first time explored the expression of ER $\beta$ pathway components in astrocytic tumors of different grades via an integrated approach and associated the tumors with patient prognosis and clinicopathological parameters. The authors demonstrated that the protein levels of ER $\beta$ and its co-activators, TIF2, AIB1 and PELP1, fluctuate as tumor grade increases in astrocytomas and are correlated with clinical and histopathological parameters [37]. Statistical analysis further indicated that $\operatorname{ER} \beta$ expression in grade II astrocytomas was significantly higher than in grade III and grade IV astrocytomas. However, ER $\beta$ expression did not significantly differ between grade III and grade IV astrocytomas. These findings were further confirmed by Liu et al. [38], who demonstrated significantly higher levels of ER $\beta$ in low grade tumors (I and II) than in high-grade tumors (III and IV). In addition, univariate analysis indicated that in the total study population, low ER $\beta$ expression and high TIF2, AIB1, and PELP1 expression were associated with decreased overall survival. However, only low ER $\beta$ expression was predictive of shorter overall survival in a subgroup analysis stratified by grade [38]. Finally, multivariate Cox analysis that included age, grade, gender, and ER $\beta$, TIF2, AIB1, and PELP1 expression revealed that high ER $\beta$ expression along with lower tumor grade were independent favorable prognostic factors of overall survival.

In summary, the expression of ER $\beta$ decreased with increased astrocytoma grade and could be a good 
Table 2: Summary of ERß-selective compounds that have been reported to be of treatment effect on malignant gliomas

\begin{tabular}{|c|c|c|c|c|}
\hline Compound & Origin & Chemical structure & Most recent results & References \\
\hline Liquiritigenin & Glycyrrhiza uralensis & & $\begin{array}{l}\text { Liquiritigenin has the } \\
\text { potential to inhibit glioma cell } \\
\text { proliferation in vitro and also } \\
\text { in vivo in xenograft-based } \\
\text { assays. }\end{array}$ & Sareddy et al. (2012) \\
\hline DPN & Synthetic & CN & $\begin{array}{l}\text { Treatment of glioma cells with } \\
\text { DPN resulted in a significant } \\
\text { dose-dependent reduction in cell } \\
\text { proliferation }\end{array}$ & Sareddy et al. (2012) \\
\hline $\begin{array}{l}\text { Monoaryl- } \\
\text { substituted } \\
\text { salicylaldoxime }\end{array}$ & Synthetic & & $\begin{array}{l}\text { These deries of compounds } \\
\text { were found to inhibit glioma } \\
\text { growth in vitro were proved to } \\
\text { be active in an in vivo xenograft } \\
\text { model of human glioma, thus } \\
\text { demonstrating the high potential } \\
\text { of this type of compounds } \\
\text { against malignant gliomas. }\end{array}$ & Paterni et al. (2015) \\
\hline TSN & $\begin{array}{l}\text { Melia toosendan Sieb. } \\
\text { et Zucc. }\end{array}$ & & $\begin{array}{l}\text { TSN is a candidate of novel } \\
\text { anti-cancer drugs for malignant } \\
\text { glioma and ER } \\
\beta \text { and p53 were prominent } \\
\text { targets for TSN. }\end{array}$ & Cao et al. (2016) \\
\hline LY500307 & Synthetic & & $\begin{array}{l}\text { LY } 500307 \text { treatment } \\
\text { significantly reduced the in vivo } \\
\text { tumor growth and promoted } \\
\text { apoptosis of glioblastoma } \\
\text { tumors in an orthotopic model } \\
\text { and improved the overall } \\
\text { survival of tumor-bearing mice. }\end{array}$ & Sareddy et al. (2016) \\
\hline
\end{tabular}

Abbreviations: DPN: 2,3-bis(4-hydroxyphenyl)-propionitrile; TSN: Toosendanin.

independent prognostic factor of patient prognosis. Unveiling the complex mechanism of tumor initiation and progression is a necessary condition for optimizing tumor diagnosis and evaluation and to design new treatment strategies that are tailored and individualized. Further studies at the clinical and molecular levels are needed to confirm the current findings and to examine whether these findings can be translated to clinical practice.

\section{VARIOUS ERß AGONISTS COULD EXERT ANTI-GLIOMA ACTIVITIES}

ER $\beta$-selective agonists are considered to be potential therapeutic agents for a wide variety of cancers [39-43]. Their development could be particularly challenging because differences in the ligand binding cavities of the two ER subtypes $\alpha$ and $\beta$ are minimal. ER $\alpha$ plays a more prominent role in the mammary gland and the uterus, preserving bone homeostasis, and regulating metabolism.
ER $\beta$ has more pronounced effects on the CNS and the immune system. Moreover, the $\beta$-subtype generally counteracts the ER $\alpha$-promoted cell hyperproliferation in tissues such as breast and uterus and is generally considered a tumor suppressor in these organs. This antiproliferative effect of ER $\beta$ has also been found in several cancer tissues, such as breast [39], prostate [40], colon [41], renal [42], pleural mesothelioma [43], and glioma [21]. Particularly, the protective effect of ER $\beta$ in gliomas is also supported by the fact that the incidence rate of this cancer is smaller in women than in men [44], and more importantly, the use of exogenous estrogens further reduces this incidence [45]. All this evidence suggests that selective activation of this receptor subtype may be exploited to obtain an antitumor effect. Here, we review the ER $\beta$-selective compounds that have been reported to be effective against malignant gliomas (Table 2).

Recently, a great number of selective ER $\beta$ agonists have been developed and are being investigated and 
considered for therapeutic use [9]. Liquiritigenin, a novel highly selective ER $\beta$ agonist, was recently isolated from the Glycyrrhiza uralensis [46]. Liquiritigenin is an active compound found in MF101 (Menerba), a plant extract previously designed to treat vasomotor symptoms (hot flashes) associated with menopause [46]. In a phase II clinical trial of Menerba [47], the drug was found to be safe, well tolerated, and taken with high compliance. It is being further evaluated for its therapeutic use in a phase III clinical trial [48]. Sareddy et al. [21] investigated the status and significance of ER $\beta$ signaling in gliomas through the use of both in vitro and in vivo xenograft models of gliomas and tested its therapeutic significance using recently developed selective ER $\beta$ modulators. Their findings indicated that ER $\beta$ agonists could promote both the expression and tumor-suppressive functions of ER $\beta$. They demonstrated that liquiritigenin significantly reduced in vivo tumor growth in a xenograft model [21]. Significantly, their results suggest that ER $\beta$ signaling plays a tumor-suppressive function in gliomas, and thus, ER $\beta$ agonists could represent a novel class of drugs for curbing glioma progression. In addition to the results described above, various other ER $\beta$-selective drugs such as ERB-041, 3,3'-diindolylmethane (DIM) should also be considered when exploring the roles of ER $\beta$ agonists in malignant glioma treatment $[8,9]$, although no reports have been published regarding their treatment effect on glioma.

Paterni et al. [11] investigated the optimization of selective ER $\beta$ agonists that were developed and improved by structural refinements of a monoaryl-substituted salicylaldoxime scaffold [49-51]. Their study described how molecular modeling revealed a simple way to introduce molecular variations that produced some salicylketoxime derivatives with significantly improved binding affinity, transactivation activity, and subtype selectivity over their aldoxime counterparts. In addition, for the first time, further pharmacological evaluations were conducted on their oxime-based ER $\beta$-agonists, both in vitro, on a glioma $\mathrm{U} 87$ cell line, and in vivo on a murine xenograft model of the same tumor.

As mentioned above, the plant-derived $\operatorname{ER} \beta$ agonist liquiritigenin has been proven to suppress the growth of subcutaneous glioma xenograft tumors [21]. In addition, salicylketoxime-based ER $\beta$ agonists have also been found to reduce glioma growth in subcutaneous models [11]. Furthermore, the new potential ER $\beta$ agonist toosendanin (TSN) has also been shown to reduce tumor burden in a xenograft model of athymic nude mice [52]. However, these studies are limited by the lack of drug testing using an orthotopic model, and furthermore, when testing the efficacy of glioma chemotherapy drugs, the tumor microenvironment and the presence of a complete immune system must be considered. Thus, using both orthotopic tumor models and a syngeneic model with an intact immune system, Sareddy et al. [53] investigated the effect of LY500307. The authors demonstrated that the selective ER $\beta$ agonist LY500307 reduced glioma progression and enhanced survival in syngeneic mouse models. As LY500307 readily crosses the BBB, it is currently being tested in clinical trials and has been found to be well tolerated. Thus significantly, it can be readily transferred to current clinical chemotherapy, thus providing an additional adjunct to improving the survival time of patients with gliomas, with limited drug toxicity.

Several efforts have been directed towards the development of ER-selective ligands [54]. In particular, significant attention has been focused on ER $\beta$-selective agonists [55], which have the potential to be used as antitumor agents because they predominantly activate the $\beta$-subtype and thus circumvent the undesired ER $\alpha$ promoted proliferative effects on the breasts and the uterus. These compounds have been proven to act as full agonists of ER $\beta$ and to activate the transcription of reporter genes and endogenous genes, thus highlighting their extremely high ER $\beta$ selectivity. These results further extend the therapeutic potential of ER $\beta$-selective agonists.

\section{CONCLUSIONS}

This review focuses on the therapeutic significance of the ER $\beta$ pathway in gliomas and suggests that functional activation of the ER $\beta$ pathway may be a potential therapeutic target for gliomas. Although ER $\beta$ has been shown to have tumor-suppressive potential, more efforts should be directed toward clarifying the exact roles of ER $\beta$ in the etiology and progression of malignant glioma. Likewise, limited information regarding which promoters drive classical ER transcription in glia or which ER $\beta$ splice variants are expressed in glia and glial tumors is currently available. Further identification of certain genes that are specifically regulated by ER $\beta$ warrants further research. Because ER $\beta$ agonists are currently being tested in clinical trials and have been well tolerated with few side effects, the identification of ER $\beta$ agonists as therapeutic agents could be readily extended to clinical use, and thus, ER $\beta$ agonists could represent a novel class of drugs for treating gliomas in the near future.

\section{CONFLICTS OF INTEREST}

The authors declare no competing financial interests.

\section{FUNDING}

This work is supported by grants from National Natural Science Foundation of China (Nos. 81372714, 81672480), Liaoning Provincial Natural Science Foundation of China (No. 201602244), Distinguished Professor Project of Liaoning Province, Special Grant for Translational Medicine, Dalian Medical University (No. 2015002). 


\section{REFERENCES}

1. Kabat GC, Etgen AM, Rohan TE. Do steroid hormones play a role in the etiology of glioma? Cancer Epidemiol Biomarkers Prev. 2010; 19:2421-7.

2. McKinley BP, Michalek AM, Fenstermaker RA, Plunkett RJ. The impact of age and sex on the incidence of glial tumors in New York State from 1976 to 1995. J Neurosurg. 2000; 93:932-9.

3. Barone TA, Gorski JW, Greenberg SJ, Plunkett RJ. Estrogen increases survival in an orthotopic model of glioblastoma. J Neurooncol. 2009; 95:37-48.

4. Pardridge WM. Transport of nutrients and hormones through the blood-brain barrier. Diabetologia. 1981; 20:246-54.

5. Batistatou A, Stefanou D, Goussia A, Arkoumani E, Papavassiliou A, Agnantis NJ. Estrogen receptor beta (ER $\beta)$ is expressed in brain astrocytic tumors and declines with dedifferentiation of the neoplasm. J Cancer Res Clin Oncol. 2004; 130:405-10.

6. Mhyre AJ, Dorsa DM. Estrogen activates rapid signaling in the brain: role of estrogen receptor $\alpha$ and estrogen receptor $\beta$ in neurons and glia. Neuroscience. 2006; 138:851-8.

7. Klinge CM. Estrogen receptor interaction with co-activators and co-repressors. Steroids. 2000; 65:227-51.

8. Lo R, Matthews J. A new class of estrogen receptor betaselective activators. Mol Interv. 2010; 10:133-6.

9. Nilsson S, Gustafsson JA. Estrogen receptors: therapies targeted to receptor subtypes. Clin Pharmacol Ther. 2011; 89:44-55.

10. Yague JG, Lavaque E, Carretero J, Azcoitia I, Garcia-Segura LM. Aromatase, the enzyme responsible for estrogen biosynthesis, is expressed by human and rat glioblastomas. Neurosci Lett. 2004; 368:279-84.

11. Paterni I, Bertini S, Granchi C, Tuccinardi T, Macchia M, Martinelli A, Caligiuri I, Toffoli G, Rizzolio F, Carlson KE, Katzenellenbogen BS, Katzenellenbogen JA, Minutolo F. Highly selective salicylketoxime-based estrogen receptor $\beta$ agonists display antiproliferative activities in a glioma model. J Med Chem. 2015; 58:1184-94.

12. Batistatou A, Kyzas PA, Goussia A, Arkoumani E, Voulgaris S, Polyzoidis K, Agnantis NJ, Stefanou D. Estrogen receptor beta $(E R \beta)$ protein expression correlates with BAG-1 and prognosis in brain glial tumors. J NeuroOncol. 2006; 77:17-23.

13. Deyrup AT, Tretiakova M, Khramtsov A, Montag AG. Estrogen receptor $\beta$ expression in vascular neoplasia: an analysis of 53 benign and malignant cases. Mod Pathol. 2004; 17:1372-7.

14. Konstantinopoulos PA, Kominea A, Vandoros G, Sykiotis GP, Andricopoulos P, Varakis I, SotiropoulouBonikou G, Papavassiliou AG. Oestrogen receptor beta $(\mathrm{ER} \beta)$ is abundantly expressed in normal colonic mucosa, but declines in colon adenocarcinoma paralleling the tumour's dedifferentiation. Eur J Cancer. 2003; 39:1251-8.

15. Pujol P, Rey JM, Nirde P, Roger P, Gastaldi M, Laffargue F, Rochefort H, Maudelonde T. Differential expression of estrogen receptor- $\alpha$ and $-\beta$ messenger RNAs as a potential marker of ovarian carcinogenesis. Cancer Res. 1998; 58:5367-73.

16. Speirs V. Oestrogen receptor $\beta$ in breast cancer: good, bad, or still too early to tell? J Pathol. 2002; 197:143-7.

17. Paruthiyil S, Parmar H, Kerekatte V, Cunha GR, Firestone GL, Leitman DC. Estrogen receptor beta inhibits human breast cancer cell proliferation and tumor formation by causing a G2 cell cycle arrest. Cancer Res. 2004; 64:423-8.

18. Hartman J, Edvardsson K, Lindberg K, Zhao C, Williams C, Ström A, Gustafsson JA. Tumor repressive functions of estrogen receptor beta in SW480 colon cancer cells. Cancer Res. 2009; 69:6100-6.

19. Paruthiyil S, Cvoro A, Tagliaferri M, Cohen I, Shtivelman E, Leitman DC. Estrogen receptor beta causes aG2cell cycle arrest by inhibitingCDK1 activity through the regulation of cyclin B1, GADD45A, and BTG2. Breast Cancer Res Treat. 2011; 129:777-84.

20. Dominguez R, Micevych P. Estradiol rapidly regulates membrane estrogen receptor alpha levels in hypothalamic neurons. J Neurosci. 2010; 30:12589-12596.

21. Sareddy GR, Nair BC, Gonugunta VK, Zhang QG, Brenner A, Brann DW, Tekmal RR, Vadlamudi RK. Therapeutic Significance of Estrogen Receptor beta Agonists in Gliomas. Mol Cancer Ther. 2012; 11:1174-1182.

22. Liu RT, Zou LB, Fu JY, Lu QJ. Promotion of rat brainderived progenitor cell neurogenesis by liquiritigenin treatment: underlying mechanisms. Neurosci Lett. 2010; 481:139-43.

23. Jacome LF, Gautreaux C, Inagaki T, Mohan G, Alves S, Lubbers LS, Luine V. Estradiol and ERbeta agonists enhance recognition memory, and DPN, an ERbeta agonist, alters brain monoamines. Neurobiol Learn Mem. 2010; 94:488-98.

24. Kim JH, Jeong IY, Lim Y, Lee YH, Shin SY. Estrogen receptor beta stimulates Egr-1 transcription via MEK1/Erk/ Elk-1 cascade in C6 glioma cells. BMB Rep. 2011; 44:452-7.

25. Jiang BH, Liu LZ. Role of mTOR in anticancer drug resistance: perspectives for improved drug treatment. Drug Resist Updat. 2008; 11:63-76.

26. Deng WJ, Nie S, Dai J, Wu JR, Zeng R. Proteome, phosphoproteome, and hydroxyproteome of liver mitochondria in diabetic rats at early pathogenic stages. Mol Cell Proteomics. 2010; 9:100-116.

27. Liu X, Wang L, Chen J, Ling Q, Wang H, Li S, Li L, Yang S, Xia M, Jing L. Estrogen receptor $\beta$ agonist enhances temozolomide sensitivity of glioma cells by inhibiting PI3K/AKT/mTOR pathway. Mol Med Rep. 2015; 11:1516-22. 
28. Moore JT, McKee DD, Slentz-Kesler K, Moore LB, Jones SA, Horne EL, Su JL, Kliewer SA, Lehmann JM, Willson TM. Cloning and characterization of human estrogen receptor beta isoforms. Biochem Biophys Res Commun. 1998; 247:75-78.

29. Leung YK, Mak P, Hassan S, Ho SM. Estrogen receptor (ER)-beta isoforms: a key to understanding ER-beta signaling. Proc Nat Acad Sci USA. 2006; 103:13162-13167.

30. Leygue E, Dotzlaw H, Watson PH, Murphy LC. Expression of estrogen receptor beta1, beta2, and beta5 messenger RNAs in human breast tissue. Cancer Res. 1999; 59:1175-9.

31. Omoto Y, Eguchi H, Yamamoto-Yamaguchi Y, Hayashi S. Estrogen receptor (ER) beta1 and ERbetacx/beta2 inhibit ERalpha function differently in breast cancer cell line MCF7. Oncogene. 2003; 22:5011-20.

32. Shaaban AM, Green AR, Karthik S, Alizadeh Y, Hughes TA, Harkins L, Ellis IO, Robertson JF, Paish EC, Saunders PT, Groome NP, Speirs V. Nuclear and cytoplasmic expression of ERbeta1, ERbeta2, and ERbeta5 identifies distinct prognostic outcome for breast cancer patients. Clin Cancer Res. 2008; 14:5228-35.

33. Li W, Winters A, Poteet E, Ryou MG, Lin S, Hao S, Wu Z, Yuan F, Hatanpaa KJ, Simpkins JW, Yang SH. Involvement of estrogen receptor $\beta 5$ in the progression of glioma. Brain Res. 2013; 1503:97-107.

34. Lindberg K, Helguero LA, Omoto Y, Gustafsson JA, Haldosén LA. Estrogen receptor $\beta$ represses Akt signaling in breast cancer cells via downregulation of HER2/HER3 and upregulation of PTEN: implications for tamoxifen sensitivity. Breast Cancer Res. 2011; 13:R43.

35. Furnari FB, Lin H, Huang HS, Cavenee WK. Growth suppression of glioma cells by PTEN requires a functional phosphatase catalytic domain. Proc Natl Acad Sci USA. 1997; 94:12479-84.

36. Guido C, Panza S, Santoro M, Avena P, Panno ML, Perrotta I, Giordano F, Casaburi I, Catalano S, De Amicis F, Sotgia F, Lisanti MP, Andò S, et al. Estrogen receptor beta $(\mathrm{ER} \beta)$ produces autophagy and necroptosis in human seminoma cell line through the binding of the Sp1 on the phosphatase and tensin homolog deleted from chromosome 10 (PTEN) promoter gene. Cell Cycle. 2012; 11:2911-21.

37. Kefalopoulou Z, Tzelepi V, Zolota V, Grivas PD, Christopoulos C, Kalofonos H, Maraziotis T, SotiropoulouBonikou G. Prognostic value of novel biomarkers in astrocytic brain tumors: nuclear receptor co-regulators AIB1, TIF2, and PELP1 are associated with high tumor grade and worse patient prognosis. J Neurooncol. 2012; 106:23-31.

38. Liu C, Zhang Y, Zhang K, Bian C, Zhao Y, Zhang J. Expression of estrogen receptors, androgen receptor and steroid receptor coactivator-3 is negatively correlated to the differentiation of astrocytic tumors. Cancer Epidemiol. 2014; 38:291-7.

39. Chang EC, Frasor J, Komm B, Katzenellenbogen BS. Impact of estrogen receptor beta on gene networks regulated by estrogen receptor alpha in breast cancer cells. Endocrinology. 2006; 147:4831-4842.

40. McPherson SJ, Hussain S, Balanathan P, Hedwards SL, Niranjan B, Grant M, Chandrasir UP, Toivanen R, Wang Y, Taylor RA, Risbridger GP. Estrogen receptor- $\beta$ activated apoptosis in benign hyperplasia and cancer of the prostate is androgen independent and TNF $\alpha$ mediated. Proc Natl Acad Sci USA. 2010; 107:3123-3128.

41. Hartman J, Edvardsson K, Lindberg K, Zhao C, Williams C, Ström A, Gustafsson JA. Tumor repressive functions of estrogen receptor $\beta$ in SW480 colon cancer cells. Cancer Res. 2009; 69:6100-6106.

42. Yu CP, Ho JY, Huang YT, Cha TL, Sun GH, Yu DS, Chang FW, Chen SP, Hsu RJ. Estrogen inhibits renal cell carcinoma cell progression through estrogen receptor- $\beta$ activation. PLoS One. 2013; 8:e56667.

43. Pinton G, Thomas W, Bellini P, Manente AG, Favoni RE, Harvey BJ, Mutti L, Moro L. Estrogen receptor $\beta$ exerts tumor repressive functions in human malignant pleural mesothelioma via EGFR inactivation and affects response to gefitinib. PLoS One. 2010; 5:e14110.

44. Carroll RS, Zhang J, Dashner K, Sar M, Black PM. Steroid hormone receptors in astrocytic neoplasms. Neurosurgery. 1995; 37:496-503.

45. Hatch EE, Linet MS, Zhang J, Fine HA, Shapiro WR, Selker RG, Black PM, Inskip PD. Reproductive and hormonal factors and risk of brain tumors in adult females. Int J Cancer. 2005; 114:797-805.

46. Mersereau JE, Levy N, Staub RE, Baggett S, Zogovic T, Chow S, Ricke WA, Tagliaferri M, Cohen I, Bjeldanes LF, Leitman DC. Liquiritigenin is a plant-derived highly selective estrogen receptor beta agonist. Mol Cell Endocrinol. 2008; 28349-57.

47. Grady D, Sawaya GF, Johnson KC, Koltun W, Hess R, Vittinghoff E, Kristof M, Tagliaferri M, Cohen I, Ensrud KE. MF101, a selective estrogen receptor beta modulator for the treatment of menopausal hot flushes: a phase II clinical trial. Menopause. 2009; 16:458-65.

48. Stovall DW, Pinkerton JV. MF-101, an estrogen receptor beta agonist for the treatment of vasomotor symptoms in peri- and postmenopausal women. Curr Opin Investig Drugs. 2009; 10:365-71.

49. Minutolo F, Bellini R, Bertini S, Carboni I, Lapucci A, Pistolesi L, Prota G, Rapposelli S, Solati F, Tuccinardi T, Martinelli A, Stossi F, Carlson KE, et al. Monoarylsubstituted salicylaldoximes as ligands for estrogen receptor $\beta$. J Med Chem. 2008; 1:1344-1351.

50. Minutolo F, Bertini S, Granchi C, Marchitiello T, Prota G, Rapposelli S, Tuccinardi T, Martinelli A, Gunther JR, Carlson KE, Katzenellenbogen JA, Macchia M. Structural evolutions of salicylaldoximes as selective agonists for estrogen receptor $\beta$. J Med Chem. 2009; 52:858-867.

51. Bertini S, De Cupertinis A, Granchi C, Bargagli B, Tuccinardi T, Martinelli A, Macchia M, Gunther JR, 
Carlson KE, Katzenellenbogen JA, Minutolo F. Selective and potent agonists for estrogen receptor beta derived from molecular refinements of salicylaldoximes. Eur J Med Chem. 2011; 46:2453-2462.

52. Cao L, Qu D, Wang H, Zhang S, Jia C, Shi Z, Wang Z, Zhang J, Ma J. Toosendanin Exerts an Anti-Cancer Effect in Glioblastoma by Inducing Estrogen Receptor $\beta$ - and p53Mediated Apoptosis. Int J Mol Sci. 2016; 17:E1928.

53. Sareddy GR, Li X, Liu J, Viswanadhapalli S, Garcia L, Gruslova A, Cavazos D, Garcia M, Strom AM, Gustafsson JA, Tekmal RR, Brenner A, Vadlamudi RK. Selective Estrogen Receptor $\beta$ Agonist LY500307 as a Novel Therapeutic Agent for Glioblastoma. Sci Rep. 2016; $6: 24185$.
54. Paterni I, Granchi C, Katzenellenbogen JA, Minutolo F. Estrogen receptors alpha $(\mathrm{ER} \alpha)$ and beta $(\mathrm{ER} \beta)$ : subtypeselective ligands and clinical potential. Steroids. 2014; 90:13-29.

55. Minutolo F, Macchia M, Katzenellenbogen BS, Katzenellenbogen JA. Estrogen receptor $\beta$ ligands: recent advances and biomedical applications. Med Res Rev. 2011; 31:364-442.

56. Pettersson K, Gustafsson JA. Role of estrogen receptor beta in estrogen action. Annu Rev Physiol. 2001; 63:165-92. 